\title{
Left ventricular hypertrabeculation/ noncompaction with epilepsy, other heart defects, minor facial anomalies and new copy number variants
}

Bert Nagel ${ }^{1}$, Ursula Gruber-Sedlmayr ${ }^{2}$, Sabine Uhrig ${ }^{3}$, Claudia Stöllberger ${ }^{4^{*}}$, Eva Klopocki ${ }^{5}$ and Josef Finsterer ${ }^{4}$

\begin{abstract}
Background: Left ventricular hypertrabeculation/noncompaction (LVHT) is a cardiac abnormality of unknown etiology which has been described in children as well as in adults with and without chromosomal aberrations. LVHT has been reported in association with various cardiac and extracardiac abnormalities like epilepsy and facial dysmorphism.
\end{abstract}

Case presentation: A unique combination of LVHT, atrial septal defect, pulmonary valve stenosis, aortic stenosis, epilepsy and minor facial anomalies is presented in a 5.5 years old girl. Microarray-based genomic hybridization (array-CGH) detected six previously not described copy number variants (CNVs) inherited from a clinically unaffected father and minimally affected mother, thus, most likely, not clinically significant but rare benign variants.

Conclusions: Despite this complex phenotype de novo microdeletions or microduplications were not detected by array CGH. Further investigations, such as whole exome sequencing, could reveal point mutations and small indels as the possible cause.

Keywords: Cardiomyopathy, Congenital heart disease, Neurology, Pediatrics, Array CGH, Hypertrabeculation, Seizures

\section{Background}

Left ventricular hypertrabeculation/noncompaction (LVHT) is a cardiac abnormality of unknown etiology which has been described in children as well as in adults. LVHT has been reported in association with various cardiac abnormalities, like Ebstein anomaly, pulmonary stenosis or atrial septal defect [1-12]. LVHT is associated with several extracardiac, especially neurological, abnormalities. LVHT has been reported in association with epilepsy, facial dysmorphism or minor anomalies [1,4,12-18]. Several chromosomal aberrations have been identified in LVHT associated with heart defects $[1,4,8,10,12,15-17]$. We present a pediatric patient with LVHT and other right and left heart defects, epilepsy and minor facial

\footnotetext{
* Correspondence: claudia.stoellberger@wienkav.at

${ }^{4}$ Krankenanstalt Rudolfstiftung, Juchgasse 25, A-1030 Wien, Austria

Full list of author information is available at the end of the article
}

anomalies in whom microarray-based comparative genomic hybridization (array CGH) detected new copy number variants $(\mathrm{CNVs})$.

\section{Case presentation}

A 5.5-year old girl had undergone surgical patch closure of a large secundum atrial septal defect with valvotomy of a moderate pulmonary stenosis at the age of 2 months; a mild aortic stenosis with a thickened tricuspid aortic valve was not corrected. She was born as the first child to non-consanguineous parents. The family history was negative for sudden cardiac death, but the maternal grandfather had epileptic seizures without fever in his youth. At the age of 12 months the girl suffered from a first afebrile seizure and at the age of 23 months from a first febrile seizure. Four months later she suffered from a series of afebrile seizures. Therefore valproic acid was started and maintained for 2 years. During this treatment she was

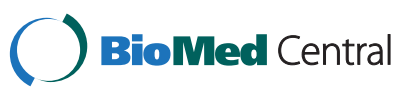




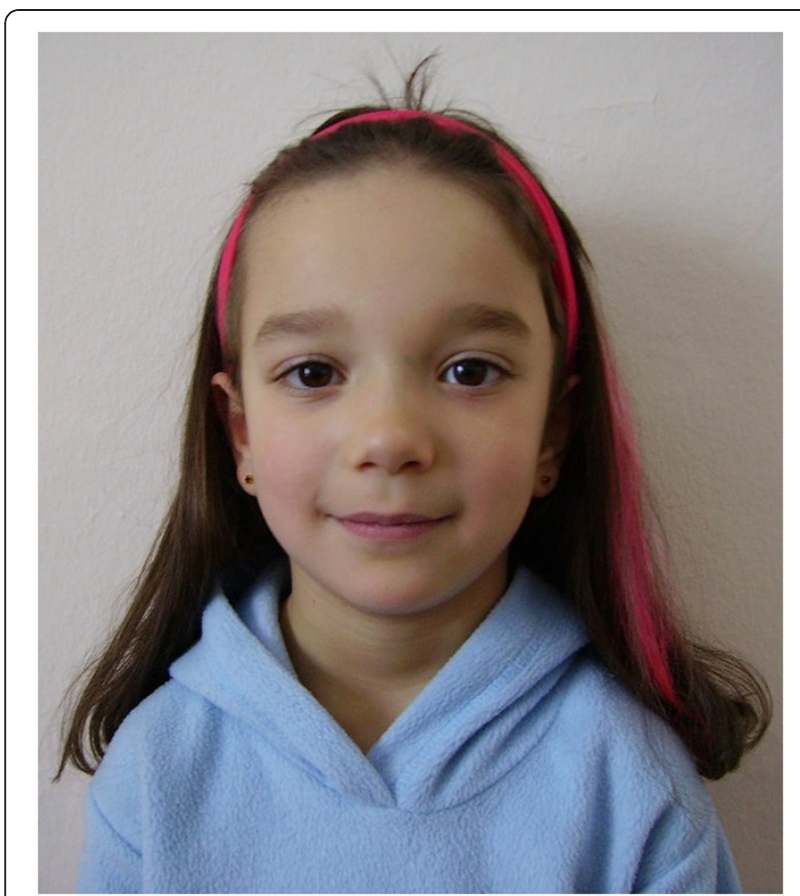

Figure 1 Frontal pictures of the patient showing bilateral epicanthic folds, broad eyebrows, broad nasal tip and hypertelorism.

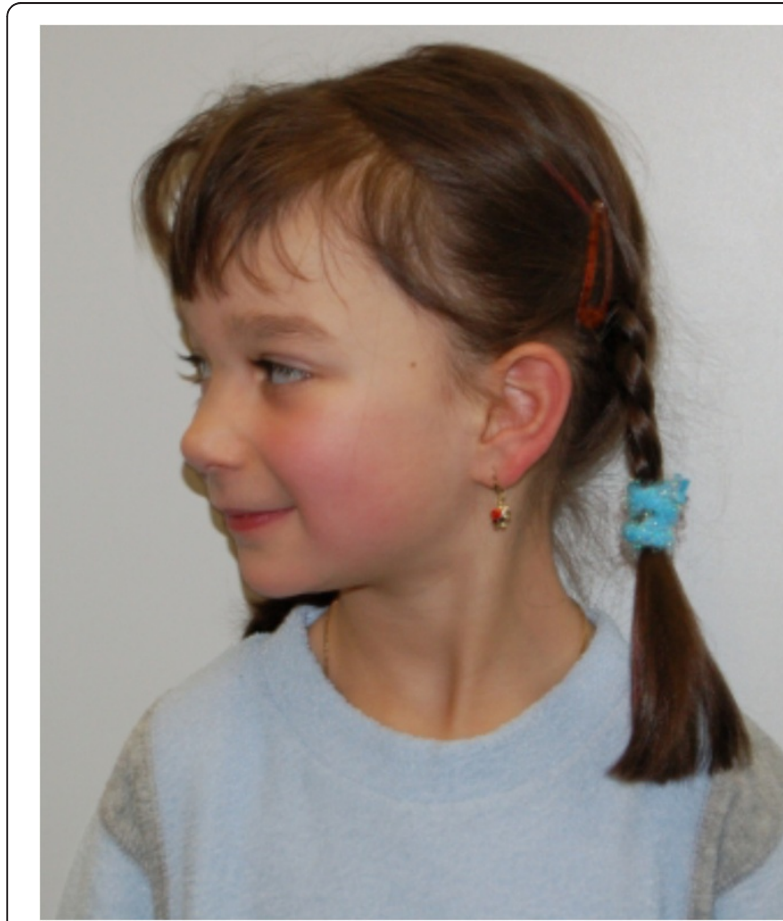

Figure 2 Lateral pictures of the patient showing bilateral epicanthic folds, broad eyebrows, broad nasal tip and hypertelorism.

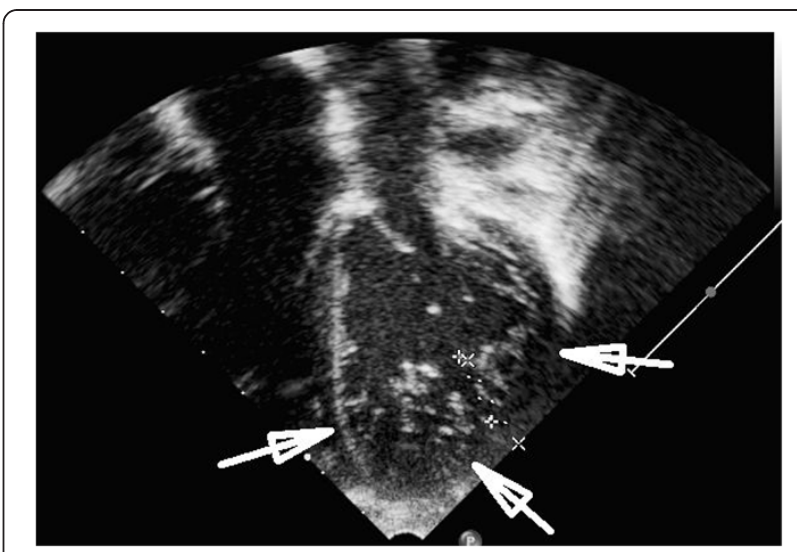

Figure 3 Echocardiographic apical 4-chamber-view showing the hypertrabeculated left ventricular apex with a two-layered structure.

seizure-free with normal electroencephalogram (EEG). After tapering valproic acid over a period of 2 months, short generalized paroxysmal discharges appeared on the EEG for the first time without clinical correlate. One year later she suffered from two further uncomplicated febrile seizures. Since then she is seizure-free without anticonvulsive treatment but the 24 h-EEG persistently shows subclinical absences. Since the intellectual and physical development of the patient is normal it was decided together with the parents not to restart the antiepileptic medication but to follow her up closely. Cerebral magnetic resonance imaging was normal. Clinical cardiologic, echocardiographic and neurologic examinations of the first degree relatives were normal except for the mother who showed epicanthic folds and hypertelorism. Unfortunately, the maternal grandfather did not consent with any investigations.

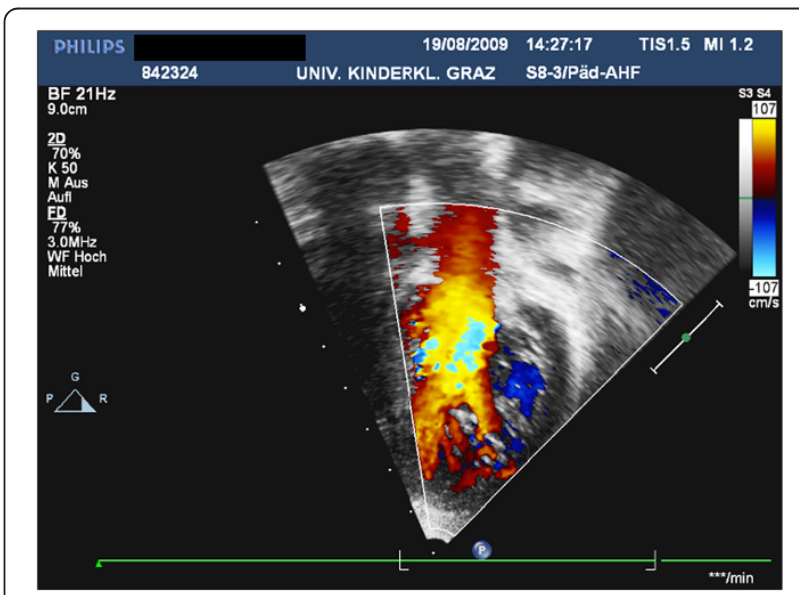

Figure 4 Using colour-Doppler-sonography the intertrabecular recesses are perfused from the ventricular cavity. 
At inspection, she had bilateral epicanthic folds; broad eyebrows, a broad nasal tip and hypertelorism, however no ptosis or low-set ears (Figures 1 and 2). Her body weight was $18 \mathrm{~kg}$ ( $25^{\text {th }}$ percentile), head circumference $51 \mathrm{~cm}\left(50^{\text {th }}\right.$ percentile) and height $115 \mathrm{~cm}\left(75^{\text {th }}\right.$ percentile). She did not complain about any cardiac symptoms and did not suffer from heart failure. Twelve-lead electrocardiogram showed normal sinus rhythm alternating with an atrio-ventricular-nodal rhythm and an incomplete right-bundle-branch-block. Twenty-four-hour electrocardiogram showed sporadic ventricular and supraventricular ectopic beats. Echocardiography revealed a mild residual valvular pulmonary stenosis with moderate pulmonary valve regurgitation and mild aortic valve stenosis with mild aortic regurgitation. Left ventricular function was normal, however, extensive hypertrabeculation resulting in a two-layered structure of the myocardium was visible in the mid-ventricular and apical segments of the left ventricle, consistent with the diagnosis of LVHT (Figures 3 and 4). Review of previous echocardiographic examinations disclosed that LVHT had been present already at age 2 years. As a primary prophylaxis for cardiac embolism aspirin $50 \mathrm{mg} / \mathrm{d}$ was started. Since she was symptom-free, no further cardiac medication was prescribed. At the latest follow-up investigation in September 2011, she was in a good cardiac and neurologic condition, no seizures had recurred and her intellectual development was normal. Echocardiography was unchanged.

Molecular genetic analyses of the PTPN11, KRAS, RAF1 and SOS1 genes were negative. Array CGH using a $1 \mathrm{M}$ oligonucleotide microarray platform (Agilent Technologies, Santa Clara, CA) was performed to screen genome- wide for submicroscopic deletions and duplications [19]. Genomic positions are given according to genome-build hg18. Array CGH detected five previously not described CNVs as listed in Table 1. FISH analyses were not carried out because of the size of the CNVs. Regarding the duplications it could not be assessed whether they were tandem-duplications on the same locus or whether the duplicated fragment was inserted or translocated in another chromosome. By application of quantitative RealTime PCR (qPCR) we could show, however, that none of the changes had developed de novo. All five CNVs are currently not listed in the Toronto Database of Genomic Variants (DGV), therefore, have to be considered as nonfrequent variants in normal controls. Follow-up and testing of the index patient and her parents by qPCR revealed that all CNVs were inherited from one of the unaffected parents (maternal: deletion 1q42.3, duplication 3q26.32q26.33; paternal: duplication 14q32.11, deletion and duplication 20q13.33). We thus conclude that these changes are most likely not clinically significant CNVs but rare benign variants, although a reduced penetrance of inherited CNVs cannot be excluded.

\section{Discussion}

LVHT associated with atrial septal defect with or without pulmonary valve stenosis has been reported by several authors $[2-9,11]$. In most of these patients atrial septal defect and LVHT were associated with several other cardiac and extracardiac anomalies, and genetic studies revealed various mutations as listed in Table 2. However, the combination of a secundum type atrial septal defect with pulmonary stenosis and aortic stenosis in combination with LVHT has not been described to date. LVHT

Table 1 Array CGH detected CNVs

\begin{tabular}{|c|c|c|c|c|c|}
\hline Chromosomal band & CNV & Start & End & Genes & \\
\hline $1 \mathrm{p} 12$ & del & 120338195 & 120404356 & $\begin{array}{l}\text { NOTCH2 } \\
\text { (intragenic, exon 2-4) }\end{array}$ & $\begin{array}{l}\text { homolog of } \\
\text { Drosophila Notch2, } \\
\text { MIM } 600275\end{array}$ \\
\hline $1 \mathrm{q} 42.3$ & del & 234409418 & 234422919 & $\begin{array}{l}\text { GPR137B } \\
\text { (intragenic, exon 5) }\end{array}$ & $\begin{array}{l}\text { G protein-coupled } \\
\text { receptor } 137 \mathrm{~B} \text {, } \\
\text { MIM } 604658\end{array}$ \\
\hline $3 q 26.32 q 26.33$ & dup & 180445165 & 180668097 & $\begin{array}{l}\text { KCNMB3 } \\
\text { (5' partial), } \\
\text { ZNF639, MFN1, GNB4 }\end{array}$ & $\begin{array}{l}\text { potassium large conductance } \\
\text { calcium-activated channel, subfamily } \\
\text { M beta member 3, MIM 605222; zinc } \\
\text { finger protein 639; Mitofusin 1, } \\
\text { MIM 608506; Guanine } \\
\text { nucleotide-binding protein } \\
\text { beta-4, MIM } 610863\end{array}$ \\
\hline $14 q 32.11$ & dup & 89942827 & 90019073 & $\begin{array}{l}\text { CALM1 } \\
\text { (3' partial) }\end{array}$ & Calmodulin 1, MIM 114180 \\
\hline $20 q 13.33$ & del & 59412001 & 59460188 & $\begin{array}{l}\mathrm{CDH} 4 \\
\text { (intronic) }\end{array}$ & $\begin{array}{l}\text { cadherin } 4 \text { (retinal cadherin), } \\
\text { MIM } 603006\end{array}$ \\
\hline $20 q 13.33$ & dup & 59597204 & 59629701 & $\begin{array}{l}\mathrm{CDH} 4 \\
\text { (intronic) }\end{array}$ & \\
\hline
\end{tabular}


Table 2 Reports about left ventricular noncompaction/hypertrabeculation with atrial septal defect

\begin{tabular}{|c|c|c|c|c|c|}
\hline Ref. & Age/sex & Additional cardiac findings & Extracardiac comorbidity & Follow-up & Genetic findings \\
\hline [2] & $39 y / f$ & Eb, heart failure, $E F<55$ & $\mathrm{NI}$ & $\mathrm{NI}$ & MYH7 mutation \\
\hline [9] & $16 y / m$ & $\begin{array}{l}\text { Right pulmonary vein } \\
\text { aplasia, left-sided } \\
\text { pulmonary vein } \\
\text { obstruction }\end{array}$ & $\begin{array}{l}\text { Right lung } \\
\text { hypoplasia }\end{array}$ & $\begin{array}{l}\text { Balloon dilatation, } \\
\text { interventional ASD } \\
\text { closure }\end{array}$ & $\mathrm{Nl}$ \\
\hline$[10]$ & $\mathrm{NI} / \mathrm{m}$ & $\begin{array}{l}\text { AV-block I, } \\
\text { syncope }\end{array}$ & $\mathrm{NI}$ & $\mathrm{NI}$ & NKX2.5 mutation \\
\hline [11] & $23 y / m$ & VSD & $\mathrm{NI}$ & $\mathrm{NI}$ & $\mathrm{Nl}$ \\
\hline$[3]$ & Birth/f & VSD & $\begin{array}{l}\text { Agenesis of } \\
\text { corpus callosum, } \\
\text { facial dysmorphism, } \\
\text { febrile seizures }\end{array}$ & $\begin{array}{l}\text { Alive at } 3 \text { years, } \\
\text { delayed } \\
\text { psychomotor } \\
\text { development }\end{array}$ & $\begin{array}{l}\text { Interstitial 1q43 } \\
\text { deletion }\end{array}$ \\
\hline$[5]$ & $16 y / m$ & None & $\mathrm{NI}$ & $\mathrm{NI}$ & E101K ACTC mutation \\
\hline$[5]$ & $62 \mathrm{y} / \mathrm{m}$ & None & $\mathrm{NI}$ & $\mathrm{NI}$ & E101K ACTC mutation \\
\hline [6] & $1 \mathrm{~m} / \mathrm{m}$ & None & $\begin{array}{l}\text { Hypotonia, developmental } \\
\text { delay, nystagmus, strabismus, } \\
\text { failure to thrive }\end{array}$ & $\mathrm{NI}$ & MMACHC mutation \\
\hline [7] & $5 \mathrm{~d} / \mathrm{m}$ & $\mathrm{EF}<55, \mathrm{PDA}, \mathrm{Eb}$ & $\mathrm{NI}$ & Alive & $\mathrm{NI}$ \\
\hline [7] & $1 d / f$ & None & $\mathrm{Ni}$ & Alive & $\mathrm{Nl}$ \\
\hline [7] & $6 \mathrm{~m} / \mathrm{m}$ & Ectopic atrial rhythm, VSD & $\mathrm{NI}$ & Alive & $\mathrm{Nl}$ \\
\hline [7] & $5 y / f$ & WPW, Eb & $\mathrm{NI}$ & Alive & $\mathrm{Nl}$ \\
\hline$[7]$ & $6 \mathrm{~m} / \mathrm{f}$ & $\mathrm{EF}<55$, VSD, SAS, Coa & $\mathrm{NI}$ & Dead & $\mathrm{Nl}$ \\
\hline [7] & $2 \mathrm{~m} / \mathrm{m}$ & VSD & $\mathrm{Nl}$ & Alive & $\mathrm{Nl}$ \\
\hline [7] & $1 \mathrm{~m} / \mathrm{f}$ & SVT, VT, VSD, PDA, DILV & $\mathrm{NI}$ & Alive & $\mathrm{NI}$ \\
\hline [7] & Birth/f & $\mathrm{EF}<55, \mathrm{PDA}$ & $\mathrm{Nl}$ & Dead & $\mathrm{Nl}$ \\
\hline [7] & $1 d / f$ & VSD, PDA, BAV, LSVC & $\mathrm{NI}$ & Alive & $\mathrm{NI}$ \\
\hline [7] & $9 \mathrm{~m} / \mathrm{f}$ & $E F<55$, VSD & $\mathrm{NI}$ & Dead & $\mathrm{NI}$ \\
\hline [7] & $2 \mathrm{~d} / \mathrm{m}$ & $E F<55$, VSD & $\mathrm{NI}$ & Dead & $\mathrm{NI}$ \\
\hline [7] & $3 \mathrm{~m} / \mathrm{m}$ & VSD & $\mathrm{Nl}$ & Alive & $\mathrm{Nl}$ \\
\hline [7] & $6 \mathrm{~d} / \mathrm{m}$ & $E F<55$ & $\mathrm{NI}$ & Alive & $\mathrm{NI}$ \\
\hline [7] & $9 \mathrm{~m} / \mathrm{m}$ & VSD & $\mathrm{NI}$ & Alive & $\mathrm{Nl}$ \\
\hline [7] & $7 d / f$ & $E F<55$ & $\mathrm{NI}$ & Alive & $\mathrm{NI}$ \\
\hline [7] & $1 \mathrm{~m} / \mathrm{m}$ & $E F<55$ & $\mathrm{Nl}$ & Alive & $\mathrm{Nl}$ \\
\hline [8] & Birth/f & $\begin{array}{l}\text { Sinusbradycardia, } \\
\text { pulmonary valve atresia }\end{array}$ & $\begin{array}{l}\text { BLI, ACV, abdominal situs } \\
\text { ambiguous, polysplenia }\end{array}$ & Dead & Linkage to $6 \mathrm{p} 24.3-21.2$ \\
\hline [8] & $22 \mathrm{y} / \mathrm{m}$ & Sinusbradycardia, AF & BLI, ACV & Alive & Linkage to $6 p 24.3-21.2$ \\
\hline [8] & $32 y / f$ & $\begin{array}{l}\text { Pulmonary valve stenosis, } \\
\text { sick sinus syndrome }\end{array}$ & $\begin{array}{l}\text { ACV, polysplenia, } \\
\text { malrotation of the gut }\end{array}$ & Alive & Linkage to $6 \mathrm{p} 24.3-21.2$ \\
\hline [8] & $59 \mathrm{y} / \mathrm{m}$ & $A F$, heart failure, $E F<55$ & Polysplenia & Died suddenly & Linkage to $6 \mathrm{p} 24.3-21.2$ \\
\hline
\end{tabular}

$\mathrm{NI}$, not indicated; $\mathrm{EF},<55$ left ventricular ejection fraction $<55 \%$; PDA, patent ductus arteriosus; Eb, Ebstein anomaly of the tricuspid valve; VSD, ventricular septal defect; WPW, Wolff-Parkinson-White; SAS, subaortic stenosis; Coa, coarctation of the aorta; SVT, supraventricular tachycardia; VT, ventricular tachycardia; DILV, double-inlet left ventricle; BAV, bicuspid aortic valve; LSVC, left-sided superior vena cava; ACV, azygous continuation of the vena cava inferior; AF, atrial fibrillation; BLI, bronchial left isomerism.

associated with seizures has been reported in children with monosomy $1 \mathrm{p} 36[1,15,16]$ and interstitial 1q43 deletion [4]. Facial anomalies and LVHT have been described previously in children with developmental impairment, interstitial 1q43 deletion [4], deletion 1p36 syndrome [1], interstitial 8p23.1 deletion [12], point mutations and deletions of the NSD1 gene located at chromosome 5q35 [17] and in an adult with sex chromosome mosaicism, male phenotype and the karyotype mos45, $\mathrm{X}(28) / 46, \mathrm{X},+$ mar $(21) / 47, \mathrm{X},+2 \operatorname{mar}(1)[18]$.

CNVs are structural genomic variants due to deletions or duplications, resulting in a copy-number change of the respective genomic region. CNVs may include entire genes, regions of transcribed sequence, or nontranscribed 
sequences. Whereas the duplication or deletion of a gene can be expected to have an effect on gene dosage, the consequences of CNVs in nontranscribed sequences are less clear [20]. According to the resolution of the applied array platform (5-10 kb genome-wide) we currently do not have evidence for a clinically relevant chromosomal imbalance i.e. gain or loss of genomic material. However, it is still possible that an underlying chromosomal abnormality either below the detection limit of the array or a balanced rearrangement which is undetectable by array CGH is causative for the described phenotype. This assumption is supported by the previously reported chromosomal defects in LVHT associated with facial anomalies, atrial septal defect and epilepsy. The presence of a chromosomal abnormality as the underlying defect is further substantiated by the fact that LVHT is particularly prevalent in young patients with chromosomal abnormalities [21].

In patients with epilepsy, an association with a truncation mutation of the KCNMB3 gene has been described which is partly affected from the duplication on chromosome 3 [22]. However, consequences of the duplication on the transcripts of this gene were not tested, and this is why such a presumed association remains speculative.

The first $\mathrm{CNV}$ detected in our patient (1p12 deletion) results in a deletion of part of the NOTCH2 gene that can be mutated in Alagille syndrome, a multisystem disorder with predominantly liver-, skeletal, ophthalomologic and renal abnormalities [23]. We consider Alagille syndrome unlikely in our patient since she did not show any of these abnormalities, although highly variable expressivity of the affected systems has been described in subjects with NOTCH2 mutations [24].

\section{Conclusions}

This case shows that childhood LVHT may be associated with other cardiac abnormalities, central nervous system disease and minor facial anomalies. Despite this complex phenotype de novo microdeletions or microduplications were not detected by array CGH. Further investigations, such as whole exome sequencing, could reveal point mutations and small indels as the possible cause.

\section{Consent}

The father of the patient has given his consent for the case report to be published.

\section{Methods}

\section{Microarray-based comparative genomic hybridization (Array CGH)}

Array CGH was performed using the $1 \mathrm{M}$ oligonucleotide array (SurePrint G3 Human CGH 1x 1 M microarray, Agilent Technologies, Santa Clara, CA). We used female reference DNA (Human Genomic DNA female,
Promega). Processing of the array was done according to the manufacturer's instructions. Extraction of microarray TIFF images had been done by "Feature Extraction" and the following data analysis was done by the "DNA Analytics 4.0" software (both Agilent Technologies, Santa Clara, CA). The following analysis settings in DNA analytics software were applied: algorithm ADM-2, filter 5 probes, $\log 2$ ratio 0.29 .

\section{Quantitative real-time PCR (qPCR)}

Genomic DNA samples of the index patient and her parents were obtained from EDTA-blood. Amplicons were located within the aberrant regions as detected by array $\mathrm{CGH}$ and in flanking regions. Primer sequences can be obtained upon request. qPCR was performed as previously described [20].

\section{Abbreviations}

Array CGH: Microarray-based comparative genomic hybridization; CNVs: Copy number variants; LVHT: Left ventricular hypertrabeculation/noncompaction.

\section{Competing interest}

The authors declare that they have no competing interests.

\section{Authors' contributions}

BN collected clinical data, performed follow-up investigations, drafted the manuscript. UG-S collected clinical data, performed follow-up investigations, drafted the manuscript. SU performed the description of the dysmorphic features and took the photographs. CS drafted the manuscript, performed literature research, corresponding author. EK carried out the molecular genetic studies and drafted the manuscript. JF drafted the manuscript and performed literature research. All authors read and approved the final manuscript.

\section{Author details}

${ }^{1}$ Department of Pediatric Cardiology, Medical University Graz, University Children's Hospital, Auenbruggerplatz 30, A-8036 Graz, Austria. ²Department of Pediatrics (U. Gruber-Sedlmayr), Medical University Graz, Auenbruggerplatz 30, A-8036 Graz, Austria. ${ }^{3}$ Institute of Human Genetics, Medical University of Graz, Harrachgasse 21/8, A-8010 Graz, Austria. ${ }^{4}$ Krankenanstalt Rudolfstiftung, Juchgasse 25, A-1030 Wien, Austria. ${ }^{5}$ Institute for Medical Genetics and Human Genetics, Charité Universitätsmedizin Berlin, Augustenburger Platz 1, D-13353 Berlin, Germany.

Received: 6 March 2012 Accepted: 25 July 2012

Published: 25 July 2012

\section{References}

1. Battaglia A, Hoyme HE, Dallapiccola B, Zackai E, Hudgins L, McDonaldMcGinn D, Bahi-Buisson N, Romano C, Williams CA, Brailey LL, Zuberi SM, Carey JC: Further delineation of deletion 1 p36 syndrome in 60 patients: a recognizable phenotype and common cause of developmental delay and mental retardation. Pediatrics 2008, 121:404-410.

2. Budde BS, Binner P, Waldmüller S, Höhne W, Blankenfeldt W, Hassfeld S, Brömsen J, Dermintzoglou A, Wieczorek M, May E, Kirst E, Selignow C, Rackebrandt K, Müller M, Goody RS, Vosberg HP, Nürnberg P, Scheffold T: Noncompaction of the ventricular myocardium is associated with a de novo mutation in the beta-myosin heavy chain gene. PLoS One 2007, 2:e1362.

3. Fazio G, Pipitone S, lacona MA, Marchi S, Mongiovi M, Zito R, Sutera L, Novo S: The noncompaction of the left ventricular myocardium: our paediatric experience. J Cardiovasc Med 2007, 8:904-908.

4. Kanemoto N, Horigome H, Nakayama J, Ichida F, Xing Y, Buonadonna AL, Kanemoto K, Gentile M: Interstitial 1q43-q43 deletion with left ventricular noncompaction myocardium. Eur J Med Genet 2006, 49:247-253. 
5. Monserrat L, Hermida-Prieto M, Fernandez X, Rodríguez I, Dumont C, Cazón L, Cuesta MG, Gonzalez-Juanatey C, Peteiro J, Alvarez N, Penas-Lado M Castro-Beiras A: Mutation in the alpha-cardiac actin gene associated with apical hypertrophic cardiomyopathy, left ventricular non-compaction, and septal defects. Eur Heart J 2007, 28:1953-1961.

6. Profitlich LE, Kirmse B, Wasserstein MP, Diaz GA, Srivastava S: High prevalence of structural heart disease in children with cb1C-type methylmalonic aciduria and homocystinuria. Mol Genet Metab 2009, 98:344-348.

7. Tsai SF, Ebenroth ES, Hurwitz RA, Cordes TM, Schamberger MS, Batra AS: Is left ventricular noncompaction in children truly an isolated lesion? Pediatr Cardiol 2009, 30:597-602.

8. Wessels MW, De Graaf BM, Cohen-Overbeek TE, Spitaels SE, de Groot-de Laat LE, Ten Cate FJ, Frohn-Mulder IF, de Krijger R, Bartelings MM, Essed N, Wladimiroff JW, Niermeijer MF, Heutink P, Oostra BA, Dooijes D, Bertoli-Avella AM, Willems PJ: A new syndrome with noncompaction cardiomyopathy, bradycardia, pulmonary stenosis, atrial septal defect and heterotaxy with suggestive linkage to chromosome $6 \mathrm{p}$. Hum Genet 2008, 122:595-603

9. De Pasquale Meyer G, Kretschmar O, Valsangiacomo Buechel ER, Kellenberger C, Bauersfeld U, Attenhofer Jost CH: Rare combination of congenital aplasia of the right pulmonary veins, left ventricular noncompaction, partial membranous obstruction of left-sided pulmonary veins and secundum atrial septal defect. Int J Cardiol 2011 152:e49-51.

10. Ouyang P, Saarel E, Bai Y, Luo C, Lv Q, Xu Y, Wang F, Fan C, Younoszai A, Chen Q, Tu X, Wang QK: A de novo mutation in NKX2.5 associated with atrial septal defects, ventricular noncompaction, syncope and sudden death. Clin Chim Acta 2011, 412:170-175.

11. Sakan H, Okayama S, Uemura S, Somekawa S, Ishigami K, Takeda Y, Kawata $H$, Horii M, Fujimoto S, Saito Y: Atrial right-to-left shunt without pulmonary hypertension in a patient with biventricular non-compaction cardiomyopathy accompanied by ventricular and atrial septal defects. Intern Med 2011, 50:1747-1751.

12. Blinder JJ, Martinez HR, Craigen WJ, Belmont J, Pignatelli RH, Jefferies JL: Noncompaction of the left ventricular myocardium in a boy with a novel chromosome 8p23.1 deletion. Am J Med Genet A 2011, 155:2215-2220.

13. Hussein A, Schmaltz AA, Trowitzsch E: Isolierte Fehlentwicklung ("Noncompaction") des Myokards bei drei Kindern. Klin Pädiatr 1999, 211:175-178.

14. Finsterer J, Stöllberger C, Gelpi E: Successful heart failure therapy in mitochondrial disorder with noncompaction cardiomyopathy. Int J Cardiovasc Imaging 2006, 22:393-398.

15. Saito S, Kawamura R, Kosho T, Shimizu T, Aoyama K, Koike K, Wada T, Matsumoto N, Kato M, Wakui K, Fukushima Y: Bilateral perisylvian polymicrogyria, periventricular nodular heterotopia, and left ventricular noncompaction in a girl with 10.5-11.1 Mb terminal deletion of $1 \mathrm{p} 36$ Am J Med Genet A 2008, 146A:2891-2897.

16. Thienpont B, Mertens L, Buyse G, Vermeesch JR, Devriendt K: Leftventricular non-compaction in a patient with monosomy 1 p36. Eur J Med Genet 2007, 50:233-236.

17. Martinez HR, Belmont JW, Craigen WJ, Taylor MD, Jefferies JL: Left ventricular noncompaction in Sotos syndrome. Am J Med Genet A 2011, 155A:1115-1118.

18. Altenberger $\mathrm{H}$, Stöllberger $\mathrm{C}$, Finsterer J: Isolated left ventricular hypertrabeculation /noncompaction in a Turner mosaic with male phenotype. Acta Cardiol 2009, 64:99-103.

19. Klopocki E, Ott CE, Benatar N, Ullmann R, Mundlos S, Lehmann K: A microduplication of the long range $\mathrm{SHH}$ limb regulator (ZRS) is associated with triphalangeal thumb-polysyndactyly syndrome. Med Genet 2008, 45:370-375.

20. Klopocki E, Mundlos S: Copy-number variations, noncoding sequences, and human phenotypes. Annu Rev Genomics Hum Genet 2011, 12:53-72.

21. Finsterer J: Cardiogenetics, neurogenetics, and pathogenetics of left ventricular hypertrabeculation/ noncompaction. Pediatr Cardiol 2009 30:659-681.

22. Lorenz S, Heils A, Kasper JM, Sander T: Allelic association of a truncation mutation of the KCNMB3 gene with idiopathic generalized epilepsy. Am J Med Genet B Neuropsychiatr Genet 2007, 144B:10-13.
23. Varadkar P, Kraman M, Despres D, Ma G, Lozier J, McCright B: Notch2 is required for the proliferation of cardiac neural crest-derived smooth muscle cells. Dev Dyn 2008, 237:1144-1152.

24. Kamath BM, Bauer RC, Loomes KM, Chao G, Gerfen J, Hutchinson A, Hardikar W, Hirschfield G, Jara P, Krantz ID, Lapunzina P, Leonard L, Ling S, $\mathrm{Ng} \mathrm{VL}$, Hoang PL, Piccoli DA, Spinner NB: NOTCH2 mutations in Alagille syndrome. J Med Genet 2012, 49:138-144.

doi:10.1186/1471-2350-13-60

Cite this article as: Nagel et al:: Left ventricular hypertrabeculation/ noncompaction with epilepsy, other heart defects, minor facial anomalies and new copy number variants. BMC Medical Genetics 2012 13:60.

\section{Submit your next manuscript to BioMed Central and take full advantage of:}

- Convenient online submission

- Thorough peer review

- No space constraints or color figure charges

- Immediate publication on acceptance

- Inclusion in PubMed, CAS, Scopus and Google Scholar

- Research which is freely available for redistribution 